\title{
Food Desertification: Situating Choice and Class Relations within an Urban Political Economy of Declining Food Access
}

\author{
MELANIE BEDORE \\ Quest University Canada
}

\begin{abstract}
While food deserts create whole sets of tangible consequences for people living within them, the problem has yet to be the subject of much normative, in-depth evaluation as an urban political economy of food access. This paper provides a critical analysis of a specific food desert and its responses, drawing on a case study of the low-income, spatially segregated North End of the small city of Kingston, Ontario, Canada. The main thrust of the paper is that the food desert remains a useful yet underexplored phenomenon through which to reveal the complexities and tensions surrounding the treatment of "choice" in a classed society. Understood as an urban political economy of declining food access, the food desert phenomenon reveals capital's complex role in the promotion or violation of dignity through the urban geographies of acquiring food for oneself, family, or household. Through the data presented here, the article also argues for a collective pause among critical scholars to radicalize, rather than reject, the role of consumer choice in a more just food system, and for further normative engagement with urban landscapes of retail consolidation.
\end{abstract}

\section{Introduction}

While the social sciences continue to advance many normative campaigns for justice, this has not been the case for over a decade of research on the food desert problem. The food desert concept is used to describe compounding low income and poor access to retail food outlets (Wrigley, Warm, \& Margetts, 2003) at scales such as the neighbourhood or census tract. Food deserts are the subject of a wealth of mostly quantitative research in fields such as public health, applied geography and critical Geographic Information Systems 
(GIS), and urban planning. At its most basic, the lack of walkable, fullservice retail food outlets in poor neighbourhoods is a problem of distributive injustice ${ }^{1}$. While food deserts create whole sets of consequences and burdens for people living within them (Ver Ploeg, et al., 2009), the problem has yet to be the subject of much normative, in-depth evaluation of the urban political economy of food access.

Such analysis is long overdue, for at least two reasons. The first is the historical magnitude and projected continuation of retail food capital flight and consolidation, which are key to understanding food deserts (Larsen \& Gilliland, 2008; McClintock, 2008; Bedore, 2013). In line with the legacy of Neil Wrigley's work (2000, 2002, 2003; Wrigley, Coe, \& Currah, 2005) in geography, food desert research is incomplete without due attention to the global retail food environment (Donald, 2013). While equal consideration must be given to the local-level socio-economic conditions affecting consumer demand in low-income areas, Wrigley's work in particular shows a decadeslong trajectory of continuous reorganization on the part of the world's most powerful food firms over the last thirty years, reflecting the historic trend of simultaneous expansion (into new global markets) and contraction (through mergers and acquisitions) (Boothman, 2009). The Canadian grocery retail trade highlights the very recent continuation of this tendency ${ }^{2}$. In light of the uncertainty of sustained growth by retail food capital brought about by food price fluctuations and global economic recession, retailers are-more so in recent years - aggressively rationalizing costs as they seek out competitive advantages and new economies of scale (eg., Wood, 2013). At the same time, research by the USDA suggests that over 23 million Americans alone live in food desert areas, with 11.5 million of those people coping with simultaneous low income, poor food access, and no personal vehicle (USDA Economic Research Service, 2009). Critical scholars throughout the social sciences are well positioned to consider these international trends and their more locallevel consequences through social justice research.

Second, limitations of current research agendas and perspectives could be better contextualized by normative approaches to the food desert problem. The problem currently has good political currency and has been thoroughly rescaled, with responses formulated and implemented at city and neighbourhood scales (through grassroots, urban planning, and mayoral initiatives, for example) through to national-level policy and programming. Nevertheless, the longevity of these efforts is uncertain, given that critics are quick to point out the mixed bag of research questions and evidence that is driving current responses ${ }^{3}$. At the same time, single interventions such as a new grocery store can make for rather draconian solutions to the complexity of poor food access, which is shaped by both the supply-side factors noted above and socioeconomic conditions of particular places. Nevertheless, they are currently the most studied food desert interventions, and the results here are similarly mixed (cf., Wrigley, 2002; Cummins et al., 2005, 2008; Sadler, Gilliland, \& Arku, 2013).

In addition, public discourse on food deserts aligns itself easily with 
condemnation of people's own poverty, poor choices, and other perceived individual-level failings. As such, it may draw focus, blame, and subsequent "disciplining" policy efforts toward low-income individuals and communities, while paying insufficient attention to the structural economic causes of the problem (Guthman, 2011; Shannon, 2013). One way to move past these limitations "may entail recognizing the multiple ways in which individuals value and interact with their food environment, rather than elevating a single optimized rationality defined primarily through nutrition and cost" (Shannon, 2013, p. 12-13), and adding approaches that "emphasize the multiple normative frameworks that shape these practices, such as how family relationships, concerns over class status, or cultural norms influence food procurement" (ibid.).

This paper takes up this call, providing a normative analysis of a particular food desert problem and its responses, drawing on a case study of the low-income, spatially segregated North End of the small city of Kingston, Ontario, Canada. Understood as an urban political economy of declining food access, the food desert phenomenon offers a novel way to critically and relationally evaluate the mundane geographies of daily life in a classed society. It is also an entry point for the study of capital's complex role in the promotion or violation of dignity through the urban geographies of acquiring food for oneself and one's family or household. As a consumptive act, food procurement is bound up with individual choice, desires, and class status, which are too often dismissed as diversions from more urgent critical evaluation and mobilization around systemic problems with the global food system and restructuring global economy. Through the data presented here, I initiate what is hopefully a collective pause among scholars to engage seriously with the food desert problem as a restriction of individual choice and autonomy that, while problematic, are important expressions of power, independence, and belonging by the poor in a consumer society.

\section{Case Study and Primary Data Collection}

This opportunity to study poor food access emerged in 2006 in Kingston, a small city located in the southeastern region of Ontario, Canada. Despite its small population of only 123,000 , it is the largest city between the major urban centres of Toronto and Ottawa. Its stable economy and sizeable middle class are owing to its status as a regional service hub and a large public sector employer (see Bedore \& Donald, 2011). Kingston has a decades-old reputation for having some of Canada's most visible socio-spatial polarization (Finnigan, 1976; Osborne \& Swainson, 1988; Lukits, 2009). North Kingston is a quintessential "wrong side of the tracks," known for an extensive history of poverty, political disenfranchisement, and concentration of high-needs populations.

The details of the store closures, North Kingston, and the city's spatialized class divide have been described elsewhere (Harris, 1981, 1988; Lee, 2000; 
Kingston Mayor's Taskforce on Poverty, 2007; Bedore \& Donald, 2011; Bedore, 2013). Most important for this study, however, is a brief profile ${ }^{4}$ of two neighbourhoods within North Kingston. First, the neighbourhood of Rideau Heights saw its closest grocery store, the Kingslake IGA, close in early 2007 (see figure 1). According to the 2011 National Household Survey, Rideau Heights has 6,432 residents, occupying 2,883 dwellings (A. Eusebio, personal communication, May 1, 2014). It houses the vast majority of the City's public housing, including row housing and high-density apartment buildings administered by over a dozen housing providers. In relation to the overall City of Kingston figures, the frequency of residents experiencing mental illness, physical disability, food insecurity, unemployment, and single parenthood is high in this neighbourhood, while car ownership, education, access to basic services, and incomes are comparatively low (City of Kingston, n.d.; Kingston Community Health Centre, 2010). For instance, data from 2006 show that $32 \%$ of residents had no secondary or post-secondary school diploma or certificate, and a further $32 \%$ had only high school education. Median family income in Rideau Heights was \$35,247 in 2005, compared to the City's median income of $\$ 69,530$ (City of Kingston, n.d.) A door-todoor survey of this neighbourhood undertaken for this research also revealed that over one third of residents in this neighbourhood may experience food insecurity within a given year.

Anecdotally, public transit service is inconsistent and generally lacking in the area. Since Rideau Heights is a residential neighbourhood bordered by industrial land and major roads, at the time of study residents had some peripheral grocery options that could be walkable depending on one's location, including a butcher, a produce vendor, and some convenience stores. The IGA was, admittedly, a strange fit for the neighbourhood: it was a mid-priced grocery store, located in a strip mall facing a major road, whose target customers were commuters, tourists, and leisure shoppers (hence the Liz Clairborne women's apparel store located next to it) rather than Rideau Heights residents. As such, it was not affordable for some people; however, it was valued as a walkable one-stop option for many of the area's carless residents.

Shortly after this closure, another took place in the Inner Harbour neighbourhood, which has a population of 7,271 residents occupying 3,694 dwellings (A. Eusebio, personal communication, May 1, 2014). While the Inner Harbour is gentrifying, it has a significant number of poor households (Statistics Canada, 2013) and a historically blue-collar economic and cultural identity (Harris, 1981). The Inner Harbour is adjacent to Kingston's waterfront and downtown area, so it enjoys somewhat better access to walkable services than the more isolated Rideau Heights, including two grocery stores, a lowercost Food Basics and a high-priced (and likely cost prohibitive) Metro. Residents living close to downtown can also access a small independent grocer and a few ethnic food retailers. Despite these possible options, Inner Harbour residents were concerned and angered by the closure of a small, nearly century-old neighbourhood grocery store called Grant's No Frills. 
This store had been an independent, family-owned business; after several decades the family sold it to the Loblaw Corporation, which closed the store in 2009 (see figure 2). Unlike contemporary food retailers that are often located on main streets and in commercially zoned areas, Grant's No Frills was constructed prior to modern zoning orthodoxies and hence had the closest possible proximity to the surrounding residential neighbourhood. While it offered almost no parking space, it was extremely walkable - and affordable - for residents at all income levels.

This study is theoretically grounded in the urban political economy tradition that embeds class relations in the space of the city and explores the role that urban development, governance, and planning can play in relieving or exacerbating inequality. The approach looks to capitalism as an overarching economic system with clear urban manifestations, namely, the spatiality of uneven power relations and distributional outcomes in the city (Cardoso \& Breda-Vásquez, 2007). The article also draws from scholarly dialogues around liberal and political-economic formulations of social justice discussed in the following section. Primary source data used for this article was collected by a triangulation of methods between 2006 and $2009^{5}$ in order to best assemble the perspectives and experiences of low-income North Kingston residents. Most relevant to this paper are the results of three focus groups held in the North End. Adult participants meeting criteria for food insecurity ${ }^{6}$ were recruited using posters placed in social service agencies, apartment building lobbies, bus shelters and on signposts. Lasting two to three hours, each focus group hosted between ten and thirteen participants. Twenty-seven people were involved in the three focus groups, nineteen of whom were women. While participants were not asked to identify whether they were members of any visible minority group, only one participant was not visibly Caucasian, with English being their non-native language. The lack of racial diversity in the focus groups is not unusual for Kingston: the 2011 National Household Survey estimates that only $6.1 \%$ of the population of the Kingston census metropolitan area (9,330 individuals) belong to a visible minority group, compared with $25.9 \%$ of Ontario's overall population (Statistics Canada, 2014). Perhaps half of participants identified themselves as being parents to children living at home. Open-ended questions were designed to explore participants' experiences accessing food within a broader framework of low income, and to probe the boundaries of participants' thinking about justice and their ideal food procurement places and experiences.

Additionally, four widely advertised, open-invitation public meetings about the No Frills closure were held in the Inner Harbour during this time, convened by a local elected city councilor and community activists in order to consider the public's options for recruiting a replacement grocery store, stopping the closure, or repurposing the vacant building. Attendees ranged in age from young post-secondary students to seniors, and-alluding to the gentrification taking place in the neighbourhood-presented as being from a range of socio-economic backgrounds. These meetings, which were eventually formalized as the New Frills Downtown Revitalization Project, 
provided a valuable opportunity to collect public comments in a less-contrived setting. I attended each of these meetings, identifying myself as a researcher and recording the proceedings in order to collect local people's reactions to the store closure and their beliefs about the obligations, motivations, and responsibilities of the parent retail company. Data was also collected from forty-two interviews with key local stakeholders, including elected officials, head bureaucrats, commercial property developers, food retailers, anti-hunger activists, retailing experts, and sustainable food systems advocates such as local farmers and paid organizers. These interviewees were targeted for their respective expertise or for their ability to contribute unique perspectives on food access and the challenges within North Kingston, food-related or otherwise. Finally, as a food researcher I inadvertently earned "insider" status with respect to local and regional food campaigns happening at the time. As such, I was privy to conversations and meetings taking place regarding food system localization and 100-mile diet-type endeavors at the time, and I draw from one particularly insightful meeting in the case analysis presented below. Each of these types of primary source data was transcribed and read multiple times by the researcher. They were coded thematically to answer larger research questions about 1) perceptions of Kingston's changing retail food landscape, 2) historical context surrounding local food desertification, and 3 ) food desertification as social injustice. Within these broad themes, a more reflexive identification of sub-themes helped to develop an appreciation for nuanced perspectives on "choice," "dignity" and other ideas covered below.

\section{Food Access as Neglected Spatial Politics of Choice and Dignity}

The issue of poor and declining food access for people with low income is intimately tied to class relations and changing geographies of the built environment in the capitalist city. There is also an undeniable relationship between individual wishes, desires, choices, and preferences and the practices of traveling to, and shopping for, food. These individual subjectivities emerge, Harvey (2000) explains, through the availability of circulating variable capital for the working classes. The prospect of spending this disposable income

\footnotetext{
generates complex relations between "needs," "wants," and "luxuries" that affect lifestyle choices, status symbols, and fashions as set by the rich, powerful, and famous. These set relative standards for the laboring poor since, as Marx also insists, the sense of well-being is a comparative rather than an absolute measure and the gap between rich and poor is just as important as the absolute conditions of sustenance. (Harvey, 2000, p. 115)
}

As Harvey emphasizes from Marx, consumption is biologically and relationally essential within capitalist accumulation, yet this process of acquiring goods and services is complicated by the emotionally charged navigation of needs, wants, consumer choice, and consumer culture. Hence, Marx is clear that relative or comparative perceptions of well-being are as 
important as the absolute measures of the same. Socio-spatial processes of food shopping and travelling to get to food reveal class disparities in the emotional consequences of unmet needs, standards, and desires. It is necessary, for this reason, to wrestle with the complex push-and-pull relationship between dignity and the built environment of consumer capitalism. On the one hand, constant restructuring/remaking of this built retail environment is a spatial strategy employed by capital that creates necessary class tensions (Harvey, 1973). When understood through the lens of neoliberal urbanism, the burdens of shifting consumer landscapes easily lend themselves to depoliticized narratives about the need for individual responsibility, entrepreneurialism, and prudence (e.g., Leitner, Peck \& Sheppard, 2007). At the same time, I show here that engagement with this oppressive geography of retail capital has the immediate individual-level benefit of enhancing dignity of economically marginalized people.

There are strong contemporary traditions of liberal philosophy within which to interpret the consequences of food deserts. Liberalism considers issues around the relationship between institutions of governance and the individual, and the values of individual freedom, preferences, choice, and dignity (Pattanaik, 2009). In their most basic form, Sen (1970, p. 87) writes that liberal values

seem to require that there are choices that are personal and the relevant person should be free to do what he likes. It would be socially better, in these cases, to permit him to do what he wants, everything else remaining the same.

Liberalism and the urban spatial form are closely intertwined because of cities' inherent diversity and uneven power relations (Katznelson, 1997), making it an important validating framework through which to understand the emotional subjectivity in food access struggles in light of capitalist class relations.

Wishes and desires are taken most seriously, perhaps, by Sen's capabilities approach (Sen, 1985, 1992, 1999; Nussbaum \& Sen, 1993; Nussbaum, 2000), developed over the past thirty years as a critique of Rawls' (1971) preoccupation with the distribution and possession of primary goods. The capabilities approach assigns great importance to people's ability to express and realize their wishes and desires. It is not commodities-objects and things - in themselves that are important, but rather how commodities enhance and enable our functionings, "what the person succeeds in doing with the commodities and characteristics at his or her command" (Sen, 1985 , p. 10). As Robeyns (2009, p. 43) summarizes, the main claim of the capabilities approach is

that in making interpersonal comparisons of advantage, we should focus on people's real or effective opportunities to do what they want to do, and to be who they want to be, instead of focusing on peoples' holdings of social primary goods or their mental states (as in certain forms of utility). These beings and doings are called a person's functionings, and include such basic functionings 
as being healthy, being sheltered, not being mentally ill, engaging in social relations, and more complex and specific functionings such as combining a career with a gender-egalitarian family life.

The approach's contribution to this study is its acknowledgement of the diversity of goals, desires, and aspirations to "be" and "do" among a heterogeneous population of individuals. For this case, people's functionings could be considered their aspirations for food procurement experiences that promote feelings of dignity, autonomy, and belonging within a broader consumer culture, and for cross-class parity and respectability more generally. These functionings, I argue, are impaired by the narrowed capability for choice in food desert conditions and their consequent exacerbation of class tensions.

The spatial embeddedness of dignity and indignity is often taken for granted, yet it situates choice and autonomy as critical to human self-actualization. For Jacobson et al. (2007, 2009), the concept draws attention to our beliefs about what standards a society formally or informally considers necessary in order for all individuals to enjoy a "good" life, beginning with basic feelings of self-respect, autonomy, and control over oneself. Dignity may be felt and honoured in the "normal, unspoken conventions of mutual respect in everyday life" (Sayer, 2007, p. 565), and understood as core feelings of self-command and autonomy, "to be in control of oneself, competently and appropriately exercising one's powers" (ibid., p. 568). Seen in this way, dignity is internally constructed and held; however, it is also profoundly social, being positively or negatively affected by interactions between individuals (Jacobson, 2007). Dignity, then, is affected by the exercising of choice and autonomy and is profoundly socio-spatial, which Jacobson understands in terms of the embeddededness of encounter in place and space.

Dignity encounters take place in specific settings, public or private social and physical environments. The dignity dimension is related to several sets of conditions: the positions of the individual or collective actors; features of the setting; and properties of the broader social order in which the setting, actors, and encounter are all situated (Jacobson et al, 2009, p. 726).

The city is a scale of particular interest with respect to the lived experiences of vulnerable populations. Within the city, for example, the habitual quest for resources such as affordable food and shelter can promote or violate alreadymarginalized people's dignity due to the myriad of challenges, burdens, disappointments, and even dangers that complicate the search for essential goods (ibid.).

Liberal values - as deployed by the capabilities approach and othersdo not preclude the importance of assessing the institutions and systems of economic production and social interaction and whether these foster the capabilities needed for people to achieve their subjective goals and values. Several contemporary political philosophers do precisely this: Young (2000, p. 33) proposes, for example, that social justice be defined as the institutional 
conditions for promoting self-development and self-determination ${ }^{7}$ of a society's members, and she is principally concerned with the forms of institutionalized oppression that prevent this, such as the limits of local democracy. Sayer's (2005) arguments about the moral significance of class also engage with people's emotional responses to class inequity, grounded firmly within "the need not only for a politics of recognition but a rejuvenated egalitarian politics of redistribution that confronts the injustice of class inequalities openly" (p. 232). Finally, Fainstein's work on the just city (2001; 2005 ; 2010) attempts to reconcile tensions surrounding democracy, diversity, competitiveness, and cohesion, acknowledging the need to grapple with competing claims from groups marginalized on economic and non-economic grounds. Her attempts are lauded for doing so without neglecting "the strong explanatory potential of the political economy tradition" (Cardoso \& Breda-Vásquez, 2007, p. 386). This project attempts to walk this same line, recognizing the importance of individual subjective dignity and freedoms within "the constraining power of the global capitalist political economy" (ibid.).

\section{North Kingston's Food Desertification as an Urban Political Economy of Food Access and Choice}

The emotional consequences of declining retail food access must be understood first of all as one only dimension of vulnerability inherent to food procurement practices for food-insecure individuals and households with low income. Life with low income and the restricted mobility that often comes with it are shaped by socio-economic factors that limit access and individuals' choice sets within retail settings (e.g., McIntyre et al., 2003; Wiig \& Smith, 2009; Dachner et al., 2010). These limitations are endemic to the processes of considering, comparing, selecting and rejecting items for purchase (Gregson, Crewe \& Brooks, 2002). North End residents situate the costs and burdens of the IGA and No Frills grocery store closures within a broader context of daily struggle with poverty, noting, for example, that

When you feed yourself [poorly], you don't feel right. You don't act right. You don't work properly. The human body is, like, don't operate well. (Inner Harbour focus group no. 2, male).

People who have families, you gotta get what you can get, you can't get all them good foods, you just gotta get what you can get. (Inner Harbour focus group no. 1 , female)

It is important to acknowledge that grocery store closures and food desertification, then, may be less dire problems in themselves and more ones that further compound the ongoing struggle to do things such as remain healthy, raise children, navigate the social welfare system, and just "get by."

Moreover, exposure to negative emotional consequences is commonplace 
for the poor even without the compounding consequences of food desertification. Reflecting Jackson et al.'s (2006) distinction between choice between stores and choice within stores, even when North Enders try to simplify their shopping habits to avoid emotional vulnerability, a gap between disposable income and a person's wants or needs can lead to embarrassment and degrading situations. These instances must be regularly endured while living on a fixed income, which is often synonymous with dependence on meager social assistance and disability payments,

[...] with the grocery stores...things are on sale, you see all these people going, buying expensive stuff, stocking up, blades of roast, you've got to get other stuff 'cause you can't afford to get it. It's embarrassing no matter what, because you don't have the money to get it. (Inner Harbour focus group no. 1, female)

Oh yeah, it's really embarrassing when you think you've got enough groceries for enough money, and you get up there, and, okay, you're ten dollars short. Okay, I have to put this back and this back and this back, and it's really embarrassing to do that, because that says 'you don't have a lot of money'. And it is embarrassing to say you don't have a lot of money, especially when you're buying food, 'cause that's an essential part of life. (Inner Harbour focus group no. 2 , female)

Embarrassment and shame are often confined to internal dialogue and feelings, but they are socially co-constructed, deriving from peoples' direct or indirect social interactions and encounters with others (eg., Chase \& Walker, 2012). These interactions make visible the disparities between others' affluence and financial freedoms (as perceived by the poor) compared with their own, whether through a glance at another shopper's cartload of food or by disrupting the flow at the checkout line to remove or return items they cannot afford.

\section{Declining Choice and its Consequences}

Through the lens of declining choice, the North Kingston grocery store closures reveal compounding emotional consequences, explored here as two dimensions of individual dignity violation and injustice. First, food desertification creates further narrowing of choice for the poor, which is an important element of self-worth in capitalist society. In the North End, residents acknowledged that the small scale and inner-city location of the No Frills made it an important part of people's personal geographies of food procurement. While it is appreciated by people with cars and no discernible barriers to retail food access (one of whom noted, "I almost go there every day. We have a car, but I walk this way, it's in the neighbourhood" [January 8 meeting, female]), its importance is far greater among people who face multiple concurrent barriers, including low income, old age, disability, carlessness, and/or limited food storage capacity in a small apartment,

When I first moved there, I didn't realize how important it was to have the 
grocery. After a while, you get really dependent on it. You have to have freezers and, like, lots of room in your home if you're gonna go out and pay money to go out and get groceries and bring them into your home, it's so much easier to go to the grocery store three times a week, stuff like that, and we have a lot of people in the neighbourhood, I think, who are living in apartments, not able to store groceries, and they need to get affordable groceries. [February 7 meeting, male]

[No Frills is] a major food source. I know a lot of people need it, they don't have transportation, they have to walk. The seniors building here at 106 Pine Street, you've got the one on Rideau Street. They were built because there was grocery sources in the neighbourhood ... the seniors can walk to buy their groceries. Now that's going to change. [January 8 meeting, male]

For various reasons, many people at the No Frills public meetings appreciate being able to make shorter trips to a small nearby store, several times a week. Among more affluent neighbourhood residents who own personal vehicles and therefore have a greater range of shopping choices available, this pattern constitutes a preference. People with limited means or mobility, with a far more restricted set of choices within a confined geographic area, also express tremendous appreciation for this store's scale and location because it accommodates their broader socio-economic constraints.

These accounts of the store's importance to people with a variety of socioeconomic situations invoke Clarke et al.'s (2004) helpful analysis of choice and retail food geographies. Food desert conditions, they suggest, can be read through their impact on already-existing levels of choice at the household level: people's choice sets are conditional not only on very household-level factors such as income and mobility but also on social and cultural 'tastes' and feelings that they are welcome and among people like them. With a nearby store closure, those people unable to overcome "the frictional effects of distance" (p. 91) therefore confront an even smaller range of choices than what is theoretically available. They are effectively deprived of the individual-level benefits of choice, the absence of which

can be disconcerting and demoralizing, whereas ample choice can empower consumers, giving them the opportunity to express themselves in a "democratic" fashion. The fundamental benefit of having retail choices available, however, is that it promotes a feeling of equitable treatment in society (ibid., p. 91).

Similarly, Dowler and Caraher (2003, p. 60) suggest that to be deprived of choice throughout one's diet and food procurement practices means that the poor are "excluded from one of the dynamic, leading sectors in society." Such is the growing recognition that dignity is embedded in choice- and payment-based practices that non-profit charities such as food pantries and hot meal programs are doing their best to create choice-based programming. For instance, Poppendieck (1998, p. 240) argues in her study of emergency food aid in the US that the importance of choice is such that "shopping is an adult activity; it implies competence and individuality, and it casts the client in an active rather than a passive role." The indignity associated with lack of 
choice represents, for these authors, a deeply problematic but understandable basis through which the social exclusion of low-income people occurs.

Through their personal accounts of food shopping constraints, North Enders support the idea that geography, in addition to factors such as food costs and cultural acceptability, further constrain one's available set of choices.

Before, when [No Frills] was down here, we could get anything. I would just go down, drop the boys off in the morning at school and then walk from there to No Frills, I'm already half-way, and then walk home. Now, it's like I have to find a ride to get out to [another inexpensive store] if I need anything. (Inner Harbour focus group no. 2, male).

But where are we going to get our groceries? [...] I bike and I walk, and I've got more metal in my ankle than - that would set off-whatever. And I can't walk that far, and I bike. I live down by the old woolen mill. So what do I do? (April 4 meeting, female)

Physical barriers such as steep hills that go unplowed in winter and short crossing times for pedestrians at busy multi-lane streets are severe enough to limit choice within people's personal geographies of food procurement even further, especially for those who are less mobile in their quest for food. When describing these physical barriers and store closures, people regularly used language such as "stressful, "emotional," and "scary," and alluded to annoyance, extra financial and time costs, and anxiety.

The food desert concept, then, could be aptly considered as a catalyst for the decline in individual autonomy through the narrowing of choice for the poorest and least mobile of residents. The most marginalized and precariously self-sustaining individuals and households will be more sensitive to minor changes in their respective landscapes of essential services, compounded by other variables affecting food access. For this reason, narrowed choice within food procurement practices stands to exacerbate both inter- and intra-class inequalities in the emotional risks of everyday consumption and social reproductive practices. Moreover, by overemphasizing the food desert problem as one of static outcomes and barren landscapes rather than as uneven processes, a variety of stakeholders (this author included) has tended to overgeneralize the breadth of the problem while failing to appreciate the heterogeneity of socio-economic conditions and resources within a community. In doing so, we may have inadvertently reproduced both those place-based narratives that may have contributed to retail capital withdrawal in the first place as well as the same power imbalances that determine who is included or excluded in defining and diagnosing food deserts. The notion of class paternalism can be a helpful way to explore such dynamics in greater detail.

\section{Class Paternalism}

The food desert problem and its effect of further narrowing food procurement options for the poor may also lend themselves to class paternalism and the 
undervaluing of choice for economically marginalized groups. As a food researcher in a small city, I saw this paternalism firsthand: in late 2008, a meeting was convened by the leaders of a food system relocalization project funded by the National Farmers' Union. The meeting, which took place at the building of a charitable meal provider in the North End, was organizedaccording to its leaders - as a discussion about creating food justice in Kingston by connecting food-insecure people with locally, sustainably grown food in a way that would pay farmers a living wage and therefore protect their livelihoods and small businesses. If poor North Enders had been present at the meeting, they would have heard comments about themselves that were far from dignity-enhancing, including this idea from a female attendee, that

the people who are especially food insecure, there seems to be a lack of knowledge of what to do with that food. When you've got a population who's been living off of convenience foods, boxed foods all their lives, being shown real foods is something new. Being told they can go to a farm and dig potatoes and take them home, well they $[. .$.$] they don't even know that a potato grows$ underground or how to do that, or what to do with it once they go home.

At the same meeting, the Loblaw's chain of grocery stores was roundly dismissed as a possible partner in creating food justice by one attendee because, as one person put it, "they're not local local." This comment alludes to regional farmers' contempt for the company's "Grown Close to Home" campaign, a rather vague, thinly veiled marketing exercise to capitalize on the popularity of locavorism. Retail food capital, it seems, has no place in a more just food system for the poor, despite the belief that the poor are, apparently, hopelessly inept when it comes to food.

This discussion - and likely others like it that are taking place within food activism circles everywhere - is prefaced on an incredibly narrow view of poor people's food knowledge, skills, and interest, matched by a similar narrow range of options for creating "food justice" for Kingston's North End. Its themes suggest that within sustainable food movements, class paternalism can manifest itself as inappropriate, unrealistic, or misguided efforts to create behavioural change or improve food access, with little attention to issues of privilege or disadvantage on the part of outside operatives. When driven by the logic that sustainable food systems in low-income communities should be fostered through self-sufficiency, such responses can deny the importance of retail capital and economic exchange to human dignity in a consumer society. To be sure, this problem is distinct from other forms of paternalism that take place within the food procurement practices. Scholars have, for instance, unveiled the underlying class, gender, and race inequities and power imbalances that can pervade alternative food practices (Delind \& Ferguson, 1999; Allen, 2004; Slocum, 2007; Guthman, 2008a, 2008b; Alkon \& Agyeman, 2011; Alkon, 2012). As well, paternalism is behind much of the indignity that many people experience when using some charitable food programs and other social services because of excessive, invasive bureaucracy or staff attitudes (Kissane, 2003; Warshawsky, 2010; Zedlewski 
et al., 2003). Shannon (2013) also understands the food desert problem as a spatialized form of "neoliberal paternalism" (Soss, Fording \& Schram, 2011), whereby sets of policies are meant to correct the disorderly, mismanaged, unhealthy lives of those in low-income communities, reforming them into economically independent, taxpaying "consumers" of state services. This framework ultimately places the responsibility for, and solutions to, obesity and other food-related problems onto the individuals living these problems.

In the case of Kingston's North End, however, paternalism can be read through the patronizing rhetoric spoken by local food elites, which shows a distinct lack of awareness of historically- and geographically-embedded class relationships within the city. The most subtle message embedded with food system relocalization rhetoric, discerned during this fieldwork, is that it is unproblematic to encourage the poor to resort to urban farming or other alternatives to resolve food access problems amidst the continuing middle-class norms of engaging with retail food capital through shopping and paying for one's food. The latter is, in fact, the way that most focus group participants wish to acquire food for themselves and their households. North Enders consistently noted their preferences for choice-based food procurement activities and acquiring food by paying for it with money. When asked to describe the "best" or "ideal" way to get groceries for themselves and their households, focus group participants are clear.

I think the best would be grocery store, because you have all these choices, and you have the money to buy food, so for me, that's the best case scenario, but even the grocery store with a little bit of money is better than going to a [charity] program. (Inner Harbour focus group no. 1, female)

It's better having your own money and going out and getting what you want. 'Cause it makes you feel good, you have money in your pocket and you want to go out, decide on what you want. (Rideau Heights focus group, female)

Having adequate money and paying for food implies here that the shopper is acting freely and independently, without resorting to charity. Engaging in economic exchange, furthermore, is an opportunity to express power and free will as a consumer, and to function in society, in one participant's words, "just like everybody else" (Inner Harbour focus group no. 2, female). In all fairness, many focus group participants did note that since the grocery store can be so demeaning for the reasons outlined earlier, using meal programs and charities can actually be preferable, provided that the staff and the ambience of the space are familiar, welcoming, and non-judgmental. By and large, however, underlying the importance of the retail transaction is the desire to enjoy entitlement, belonging, cross-class parity, and the respectability (Young, 1990) afforded to people who fit within conventions of the "professional" way of life in modern consumer society.

For some North Enders, the desire for alternative food provisioning did also include gardening, communal non-monetary cooperatives, and buying locally. Resisting the above stereotype that poor people uniformly lack 
knowledge, skills, or interest in food and cooking (Mclaughlin, Tarasuk \& Kreiger, 2003; Stead et al., 2004), focus group participants showed interest in the locality and seasonality of food, and a minority of people in each focus group were interested in alternatives such as food workshares, community gardens, or community-owned food stores as ways that North End residents could have access to healthier, low-cost, locally grown, and/or culturally appropriate foods,

I think that with, like a cooperative, you could only take local growers, then it would booster our economy up, 'cause our farmers are going bankrupt also, and we would only be supplying our stores with Ontario-grown products. (Inner Harbour focus group no. 2, female)

Yeah, even as an incentive to help something like what's being started in community gardens... here, you want something out of it? Well, put maybe an hour of work into it. Even weeding for an hour in a garden will help out a garden, and it also gets you your food, which will help you out. And a lot of people can put away, like, an hour, maybe once a week to go do something, maybe even more [...] (Inner Harbour focus group no. 2, male)

While North Enders were not aware of the food justice meeting noted above and did not comment on it during this research, several focus group comments encapsulate the familiar tensions around localism: they feel confident that we should all, presumably, be eating more food that is some variation of homegrown, local or organic, in line with the dominant discourses around the ethics of contemporary global food politics, while at the same time recognizing the income-related challenges to doing so.

You really start to get into the food politics. You know. We're starting to get into more politics, we're starting to transgress from survival. You know, what about people who want to buy fair trade, but you don't have money? I don't have money. I buy the cheapest thing I can, what's on sale, unless it's bad, and I won't buy something that's noticeably bad. But I always buy on sale. (Inner Harbour focus group no. 1 , female)

Questions of paternalism and unequal class relations arise, however, when non-market provisioning activities (which are pursued for pleasure, symbolic politics, or as a seasonal supplement to food shopping by the vast majority of the middle class who undertake them) are encouraged as solutions to food access problems or as a means of self-sufficiency.

The reproduction of uneven power relations between privileged food movement elites and the poor raises important questions about social justice. In particular, class paternalism in alternative food practices nicely illustrates Young's (1990) notion of cultural imperialism, "the universalization of a dominant group's experience and culture, and its establishment as the norm" (ibid., p. 59). As shown in the Kingston example, food desert debates and interventions (absent of the very people targeted for assistance) may exacerbate stigma and oppressive class relations by providing an additional 
channel through which the poor find themselves and their alleged foodrelated failings, as Young suggests,

[...] defined from the outside, positioned, placed, by a network of dominant meanings they experience as arising from elsewhere, from those with whom they do not identify and who do not identify with them. Consequently, the dominant culture's stereotyped and inferiorized images of the group must be internalized by group members at least to the extent that they are forced to react to behavior of others influenced by those images (Young, 1990, pp. 59-60).

Food desert responses whose momentum comes primarily from places and people of relative privilege may represent a highly localized form of cultural imperialism based on hardened ideas about class. Food desert responses, then, should be considered in light of this form of oppression, interrogating the notion that, since they already have access problems, the poor are an ideal "target market" to become the drivers of certain forms of food system change. Under the guise of education, such a goal requires that people somehow overcome their wishes for middle class comforts and standards, while the middle class continues, by and large, those very same consumerist practices. In other words, attempts to create the conditions for economically vulnerable people to "go first" in the incremental movement toward broader long-term food system change may deny those same people dignity as it is presently constituted in their lives.

\section{Concluding Discussion}

The arguments presented here are meant to strengthen the "return" of class to social science and geographical research agendas, in line with emerging perspectives "more concerned with the ways that class as an identity is forged and experienced" (Dowling, 2009, p. 834). To this point, the food desert problem has been studied primarily within scientific and distributive paradigms to gain insights about causal and correlative relationships between diet, health, race, class, food environment conditions, and food access amidst the new retail geography (Wrigley \& Lowe, 1996). When understood as landscapes of poor and declining retail food access resulting from retail food capital restructuring and consolidation, however, food deserts tell a far richer story about the struggles for class parity and dignity in everyday life.

This paper has attempted to address the lack of normative analysis of the food desert phenomenon as the narrowing of choice for the underclass. Through the data presented here, I have argued that the fact that "each person's ability to choose, to be a consumer, is both a fundamental right and fundamentally flawed" (Shannon, 2013, p. 11) should not deny low-income people's aspirations for middle-class comforts and norms in the everyday routines of life. This normative proposition is distinct from the trap of "normalizing middle-class 'foodscapes' as a model for low-income areas" (ibid., p. 2), which only reinforces a static, homogenized understanding of 
food access within a geographic area; there is room for attention to middleclass capabilities that go beyond a purely distributive approach to food deserts. Disparities in class capabilities - between who is able and unable to "be" and "do" as they wish in their consumption practices - are reminders that middle-class norms act as benchmarks against which people perceive their own relative well-being or deprivation. Among elites advocating for local food system change, there can be a lack of sensitivity to the power of these benchmarks in the lives of the poor and to the multiple meanings of "choice" across classes and income levels. In the process of struggling toward a more sustainable food system, middle-class norms and procurement habits should be the targets of initial change, bringing food options that are, for the most part, currently within the realm of niche markets to the foreground of consumer demand (Donald, 2008). As long as the middle class engages only marginally with non-market or sustainable foodways, the poor will continue to derive dignity through capitalist consumerism, and understandably so. If food system activists and change agents truly aspire to change the food system one bite - or dollar - at a time, they must start with those who set the standards to which struggling people aspire.

Unlike conventional research approaches to the food desert problem, this study does not attempt to measure the absolute costs and burdens of food desertification on a heterogeneous population. Rather, it builds on points in recent liberal thinking about social justice and the subjectivity of human self-actualization. That advocates of global food system change and postcapitalist food systems may unwittingly become agents in these oppressive local class relations by perpetuating paternalistic and cultural-imperialistic attitudes toward the poor is pernicious indeed. Failing to show sensitivity to the complexity of "choice" for diverse socio-economic groups in late consumer capitalism is just one example of the ways that, in some instances, local food elites may reinforce class disparities rather than overcome them.

The class politics of choice and autonomy-who has them, who doesn't, and why - are a neglected but important dimension of urban food justice debates. It is hoped that the data presented here advance the need for a radical politics of choice within multidisciplinary food studies and political economy by creating stronger conceptual links between normative theory and class politics as they play out in the mundane yet conflictladen practices of everyday life. In particular, ongoing research is needed to understand alternative food practices and discourses not only as they have been presented here as unwitting agents of the reproduction of urban class relations, but also through the hopeful lens of cross-class bridging and solidarity. At the same time, much could be learned by overcoming the dichotomy of "conventional" and "alternative" food business; rather than assuming a complete incompatibility between scaled-up food retail capital and everything else, food justice and planning research and practice would be better served, Donald (2008) argues, by engaging more profoundly with food firm dynamics in order to identify lessons in capacity building, up-scaling, and sustainable regional development. This article offers a first step in this 
direction, asserting that the food desert problem must firstly be brought into public discussion as a divisive spatial politics of oppression.

\section{Notes}

1 Distributive justice studies are principally concerned with the distribution of resources in society and the principles by which these are justly or unjustly allocated (see Rawls, 1971; Herbert \& Smith, 1979; Badcock, 1984; also Young's [1990] critique of the distributive paradigm of social justice).

2 Two recent domestic examples illustrate this well. In June 2013 Safeway's Canadian assets were acquired by Sobeys, the country's second largest grocery retailer. The $\$ 5.8$ billion acquisition is expected to realize significant economies of scale, and allow Sobeys to intensify its market presence in Western Canada (Strauss \& Ladurantaye, 2013). In July 2013, the Loblaw Corporation - Canada's largest grocery retailerpurchased the country's largest drugstore chain, Shopper's Drug Mart, for \$12.4 billion (Marotte, 2013).

3 The literature on food deserts and food environments is far too vast to summarize here; however, readers may further explore aggregate results and systematic reviews (Beaulac, Kristjansson \& Cummins, 2009; Walker, Keane \& Burke, 2010), contrasting studies about whether food deserts exist, where, and in what form (Leete, Bania \& Sparks-Ibanga, 2011; Short, Guthman \& Raskin, 2007), and studies measuring food deserts' effect on outcomes such as fruit and vegetable consumption, obesity, and dietrelated disease (Pearson et al., 2005; Bodor et al., 2008; Franco et al., 2009).

4 The City of Kingston's most recent in-depth neighbourhood profiles are based on the 2006 census. At the time of submission, the City was able to provide basic population information presented here based on the 2011 National Household Survey; however, more detailed figures will not be available for some time.

5 While they do not appear in this article, the results presented here are shaped by additional primary data collected in a reminiscing exercise with older Kingston residents at a long-term care facility, over 350 door-to-door surveys of Rideau Heights residents, and archival research on the changing retail food landscapes of the city and the capitalization of the retail food sector.

6 Pursuant to those used in the 1998-99 National Health Population Survey (Dietitians of Canada, 2005), indicators of food insecurity were, at any time in the last year, not having enough food to eat because of lack of money, worrying that there wouldn't be enough to eat because of lack of money, or not eating the quality or variety of foods that you would like, because of a lack of money.

7 Young (2000, p. 33) defines self-development as heterogeneous individuals' ability to participate in determining their actions and the conditions of their actions.

\section{References}

Alkon, A.H. (2012). Black, White, and Green: Farmers 'Markets, Race, and the Green Economy. Athens \& London: University of Georgia Press.

Alkon, A.H., Agyeman, J. (Eds.). (2011). Cultivating Food Justice: Race, Class, and Sustainability. Cambridge: MIT Press.

Allen, P. (2004). Together at the Table. Pennsylvania: Pennsylvania State University Press.

Badcock, B. (1984). Unfairly Structured Cities. Oxford: Basil Blackwell.

Beaulac, J., Kristjansson, E., \& Cummins, S. (2009). A systematic review of food deserts, 19662007. Preventing Chronic Disease 6(3). http://www.cdc.gov/pcd/issues/2009/jul/08_0163. htm. Accessed 29 September 2010.

Bedore, M. 2013. Geographies of capital formation and rescaling: A historical-geographical approach to the food desert problem. The Canadian Geographer, 57(2), 133-153.

Bedore, M., \& Donald, B. (2011). Revising the politics of class in urban development: Evidence 
from the study of the social dynamics of economic performance. Urban Affairs Review, 47(2), 183-217.

Bodor, J.N., Rose, D., Farley, T.A., Swalm, C., \& Scott, S.K. (2008). Neighbourhood fruit and vegetable availability and consumption: The role of small food stores in an urban environment. Public Health Nutrition 11(4), 413-420.

Boothman, B.E.C. (2009). "A more definite system": The emergence of retail food chains in Canada, 1919-1945. Journal of Macromarketing, 29(1), 21-36.

Cardoso, R., \& Breda-Vásquez, I. (2007). Social justice as a guide to planning theory and practice: Analyzing the Portugese planning system. International Journal of Urban and Regional Research, 31(2), 384-400.

Chase, E., \& Walker, R. (2012). The co-construction of shame in the context of poverty: Beyond a threat to the social bond. Sociology. DOI: 10.1177/0038038512453796

City of Kingston. (n.d.). Neighbourhood profiles (Census 2006) - Rideau Heights. http://www. cityofkingston.ca/documents/10180/94869/NH24 RideauHeights.pdf

Clarke, I., de Kervenoael, R., Perez del Aguila, R., Hallsworth, A., Jackson, P., \& Kirkup, P. (2004). Retail competition and consumer choice: Contextualizing the "food deserts' debate". International Journal of Retail and Distribution Management, 32, 89-99.

Cummins, S., Petticrew, M., Higgins, C., Finley, A., \& Sparks, L. (2005). Large scale retailing as an intervention for diet and health: Quasi-experimental evaluation of a natural experiment. Journal of Epidemiology and Community Health, 59, 1035-1040.

Cummins, S., Findlay, A., Higgins, C., Petticrew, M., Sparks, L., \& Thomson, H. (2008). Reducing inequalities in health and diet: Findings from a study on the impact of a food retail development. Environment and Planning A, 40(2), 402-422.

Dachner, N., Riccuito, L., Kirkpatrick, S.I., \& Tarasuk. V. (2010). Food purchasing and food insecurity among low-income families in Toronto. Canadian Journal of Dietetic Practice and Research, 71(3), e50-e56.

Delind, L., \& Ferguson, A.E. (1999). Is this a women's movement? The relationship of gender to community-supported agriculture in Michigan. Human Organization, 58, 190-200.

Dietitians of Canada. (2005). Individual and household food insecurity in Canada: position of Dietitians of Canada. Retrieved May 28, 2008, from http://www.dietitians.ca/news/ downloads/Food Insecurity position.pdf

Donald, B. (2008). Food systems planning and sustainable cities and regions: The role of the firm in sustainable food capitalism. Regional Studies, 42(9), 1251-1262.

Donald, B. (2013). Food retail and access after the crash: Rethinking the food desert problem. Journal of Economic Geography, 13(2), 1-7.

Dowler, E., \& Caraher, M. (2003). Local food projects - the new philanthropy? Political Quarterly, 74(1), 57-65.

Dowling, R. (2009). Geographies of identities: Landscapes of class. Progress in Human Geography, 33(6), 833-839.

Fainstein, S.S. (2001). Competitiveness, cohesion, and governance: Their implications for social justice. International Journal of Urban and Regional Research, 25(4), 884-888.

Fainstein, S.S. (2005). Cities and diversity: Should we want it? Can we plan for it? Urban Affairs Review, 41(1), 3-19.

Fainstein, S.S. (2010). The Just City. Ithaca, NY: Cornell University Press.

Finnigan, J. (1976). Kingston: Celebrate this city. Toronto: McLelland and Stewart.

Franco, M., Diez-Roux, A. V., Nettleton, J. A., Lazo, M., Brancati, F., Cabellero, B.,

Glass, T., \& Moore, L. V. (2009). Availability of healthy foods and dietary patterns: The multiethnic study of atherosclerosis. American Journal of Clinical Nutrition, 89(3), 897-904.

Gregson, N., Crewe, L., \& Brooks, K. (2002). Shopping, space, and practice. Environment and Planning D: Society and Space, 20, 597-617.

Guthman, J. (2008a). Bringing good food to others: Investigating the subjects ofalternative food practice. Cultural Geographies, 15, 431-447.

Guthman, J. (2008b). "If they only knew": Color blindness and universalism in California alternative food institutions. The Professional Geographer, 60(3), 387-397.

Guthman, J. (2011). Weighing in: Obesity, food justice and the limits of capitalism. Berkeley: University of California Press.

Harris, R. (1981). Class struggle in the domain of social reproduction: The political significance of residential segregation in Kingston, Ontario, 1961-1976 (unpublished doctoral dissertation). 
Queen's University, Kingston, Ontario.

Harris, R. (1988). Democracy in Kingston: A social movement in urban politics 1965-1970. Montreal: McGill-Queen's University Press.

Harvey, D. (1973). Social justice and the City. London: Edward Arnold.

Harvey, D. (2000) Spaces of Hope. Berkeley \& Los Angeles: University of California Press.

Herbert, D.T., \& Smith, D.M. (Eds). (1979). Social Problems in the City. Oxford: Oxford University Press.

Jackson, P., Perez del Aguila, R., Clarke, I., Hallsworth, A., de Kervenoael, R., \& Kirkup, M. (2006). Retail restructuring and consumer choice 2. Understanding consumer choice at the household level. Environment and Planning A, 38, 47-67.

Jacobson, N. (2007). Dignity and health: A review. Social Science \& Medicine, 64, 292-302.

Jacobson, N., Oliver, J., \& Koch, A. (2009). An urban geography of dignity. Health \& Place, 15(3), 725-731.

Katznelson, I. (1997). Social justice, liberalism and the city: Considerations on David Harvey, John Rawls and Karl Polanyi. In A. Merrifield, \& E. Swyngedouw (Eds.), The Urbanization of Injustice (pp. 18-44). New York: New York University Press.

Kingston Community Health Centres. (2010). If I could change one thing... A community needs assessment of north Kingston neighbourhoods. Kingston, ON.

Kingston Mayor's Task Force on Poverty. (2007). Ready to do better: Report of the Mayor's Task Force on Poverty. Retreived from http://vibrantcanada.ca/files/kingston_poverty_task force_report.pdf

Kissane, R. J. (2003). What's need got to do with it? Barriers to use of nonprofit social services. Journal of Sociology and Social Welfare, 30(2), 127-148.

Larsen, K., \& Gilliland, J. (2008). Mapping the evolution of 'food deserts' in a Canadian city: Supermarket accessibility in London, Ontario, 1961-2005. International Journal of Health Geographics, 7(16). DOI:10.1186/1476-072X-7-16

Lee, K.K. 2000. Urban Poverty in Canada: A Statistical Profile. Canadian Council on Social Development. http://www.ccsd.ca/pubs/2000/up/

Leete, L., Bania, N., \& Sparks-Ibanga, A. (2011). Congruence and coverage: Alternative approaches to identifying urban food deserts and food hinterlands. Journal of Planning Education and Research. DOI: 10.1177/0739456X11427145

Leitner, H., Peck, J., \& Sheppard, E. (Eds.). (2007). Contesting neoliberalism: Urban frontiers. New York: Guilford.

Lukits, S. (2009). City of island communities. Kingston Life, 11(4), 20.

Marotte, B. (2013, July 15). Loblaw to buy Shoppers Drug Mart for \$12.4-billion. Globe and Mail. http://m.theglobeandmail.com/report-on-business/loblaw-to-buy-shoppers-drug-martfor-124-billion/article13215651/?service=mobile

McClintock, N. (2008). From industrial garden to food desert: Demarcated devaluation in the Flatlands of Oakland, California. Working Paper, University of California, Berkeley.

McIntyre, L., Officer, S., \& Robinson, L.M. (2003). Feeling poor: The felt experience of lowincome lone mothers. Affilia, 18(3), 316-331.

Mclaughlin, C., Tarasuk, V., \& Kreiger, N. (2003). An examination of at-home food preparation activity among low-income, food-insecure women. Journal of the American Dietetic Association, 103(11), 1506-1512.

Nussbaum, M.C. (2000). Women and human development: The capabilities approach. Cambridge: Cambridge University Press.

Nussbaum, M.C., \& Sen, A. (Eds). (1993). Quality of life. New York: Oxford University Press.

Osborne, B., \& Swainson, D. (1988). Kingston: Building on the past. Westport, ON: Butternut Press.

Pearson, T., Russell, J., Campbell, M.J., \& Barker, M.E. (2005). Do 'food deserts' influence fruit and vegetable consumption?-A cross-sectional study. Appetite, 45(2), 195-197.

Pattanaik, P.K. (2009). Rights, individual preferences and collective rationality. In K. Basu, \& R. Kanbur (Eds.), Arguments for a Better World: Essays in Honor of Amartya Sen (pp. 213-230). Oxford \& New York: Oxford University Press.

Poppendieck, J. (1998). Sweet charity? Emergency food and the end of entitlement.New York: Penguin.

Rawls, J. (1971). A Theory of Justice. Cambridge: Harvard University Press.

Robeyns, I. (2009). Justice as fairness and the capability approach. In K. Basu, \& R. Kanbur 
(Eds.), Arguments for a Better World: Essays in Honor of Amartya Sen (pp. 397-413). Oxford \& New York: Oxford University Press.

Sadler, R.C., Gilliland, J.A., \& Arku, G. (2013). A food retail-based intervention on food security and consumption. International Journal of Environmental Research and Public Health, 10, $3325-3346$.

Sayer. A. (2005). The Moral Significance of Class. Cambridge: Cambridge University Press.

Sayer, A. (2007). Dignity at work: Broadening the agenda. Organization, 14(4), 566-581.

Sen, A. (1970). Collective choice and social welfare. San Francisco: Holden-Day, Inc.

Sen, A.K. (1982). Poverty and famines: An essay on entitlement and deprivation. Oxford: Oxford University Press.

Sen, A. (1985). Commodities and Capabilities. Oxford: Oxford University Press.

Sen, A. (1992). Inequality Reexamined. Oxford: Oxford University Press.

Sen, A. (1999). Development as Rreedom. Oxford: Oxford University Press.

Shannon, J. (2013). Food deserts: Governing obesity in the neoliberal city. Progress in Human Geography. DOI: 10.1177/0309132513484378

Shaw, H.J. (2006). Food deserts: Towards the development of a classification. Geografiska Annaler: Series B, Human Geography, 88(2), 231-247.

Short, A., Guthman, J., \& Raskin, S. (2007). Food deserts, oases, or mirages? Small markets and community food security in the San Francisco Bay Area. Journal of Planning Education and Research, 26(3), 352-364.

Slocum, R. (2007). Whiteness, space, and alternative food practice. Geoforum, 38, 520-533.

Soss, J., Fording, R.C., \& Schram, S. (2011). Disciplining the poor: Neoliberal paternalism and the persistent power of Race. Chicago: University of Chicago Press.

Statistics Canada (2014). NHS Focus on Geography Series - Kingston. http://www12.statcan. gc.ca/nhs-enm/2011/as-sa/fogsspg/Pages/FOG.cfm?lang=E\&level=3\&GeoCode $=521$

Statistics Canada. (2013). Kingston CMA: Percentage of the population below after-tax lowincome measure in 2010 by 2011 census tract (CT). 2011 National Household Survey, Geography Division. http://www12.statcan.gc.ca/nhs-enm/index-eng.cfm

Stead, M., Caraher, M., Wrieden, W., Longbottom, P., Valentine, K., \& Anderson, A. (2004). Confident, fearful and hopeless cooks: Findings from the development of a food-skills initiative. British Food Journal, 106(4), 274-284.

Strauss, M., \& Ladurantaye, S. (2013, June 12). Sobeys snaps up Safeway in Western push. Globe and Mail. http://www.theglobeandmail.com/report-on-business/sobeys-to-buy-safewayin-58-billion-deal/article12499648/

USDA Economic Research Summary. (2009). ERS Report Summary. http://www.ers.usda.gov/ media/242654/ap036_reportsummary_1_.pdf

Ver Ploeg, M., Breneman, V., Farrigan, T., Hamrick, K., Hopkins, D., Kaufman, P., et al. (2009). Access to affordable and nutritious food-Measuring and understanding food deserts and their consequences: Report to Congress. USDA Economic Research Service. http://www.ers. usda.gov/publications/ap-administrative- publication/ap-036.aspx\#.UfVwERbMdUQ

Walker, R.E., Keane, C.R., \& Burke, J.G. (2010). Disparities and access to healthy food in the United States: A review of food deserts literature. Health \& Place, 16(5), 876-884.

Warshawsky, D.N. (2010). New power relations served here: The growth of food banking in Chicago. Geoforum, 41, 763-775.

Whelan, A., Wrigley, N., Warm, D., Cannings, E. (2002). Life in a 'food desert'. Urban Studies 39(11), 2083-2100.

Wiig, K., \& Smith, C. (2009). The art of grocery shopping on a food stamp budget: Factors influencing the food choices of low-income women as they try to make ends meet. Public Health Nutrition, 12(10), 1726-1734.

Wood, S. (2013). Revising the US food retail consolidation wave: Regulation, market power and spatial outcomes. Journal of Economic Geography, 13(2), 299-326.

Wrigley, N. (2000). The globalization of retail capital: Themes for economic geography. In G.L. Clark, M.P. Feldman, \& M.S. Gertler (Eds.), Oxford Handbook of Economic Geography (pp. 292-313). Oxford: Oxford University Press.

Wrigley. N. (2002). 'Food deserts' in British cities: Policy context and research priorities. Urban Studies, 39(11), 2029-2040.

Wrigley, N., Coe, N.M., \& Currah, A. (2005). Globalizing retail: Conceptualizing the distributionbased transnational corporation (TNC). Progress in Human Geography, 29(4), 437-457. 
Wrigley, N., \& Lowe, M. (Eds.). (1996). Retailing, consumption and capital. London: Longman Group Limited.

Wrigley, N., Warm, D., \& Margetts, B. (2003). Deprivation, diet and food retail access: Findings from the Leeds 'food deserts' Study. Environment and Planning A, 35(1), 151-188

Young, I.M. (1990). Justice and the Politics of Difference. Princeton, NJ: Princeton University Press.

Young, I.M. (2000). Inclusion and Democracy. Oxford: Oxford University Press.

Zedlewski, S.R., Nelson, S., Edin, K., Koball, H.L., Pomper, K., \& Roberts, T. (2003). Families coping without earnings or government cash assistance. Assessing the New Federalism Occasional Paper no. 64. http://www.urban.org:80/publications/410634.html

\section{Acknowledgement}

Many thanks to Luisa Veronis for her comments and encouragement on an earlier draft of this paper and to the two anonymous reviewers for their comments.

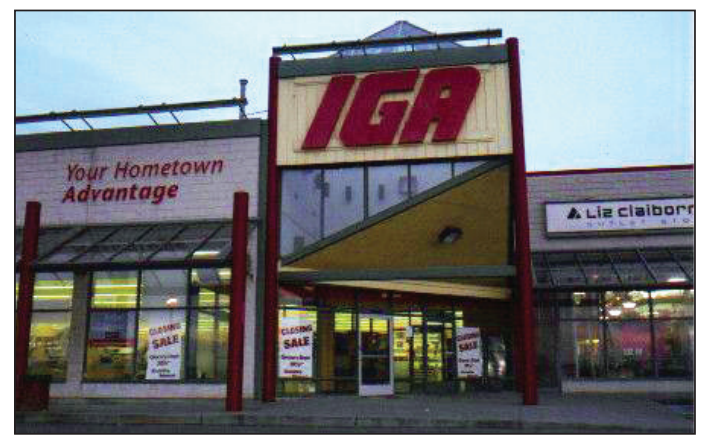

Figure 1: Kingslake IGA, 2006

Source: Author

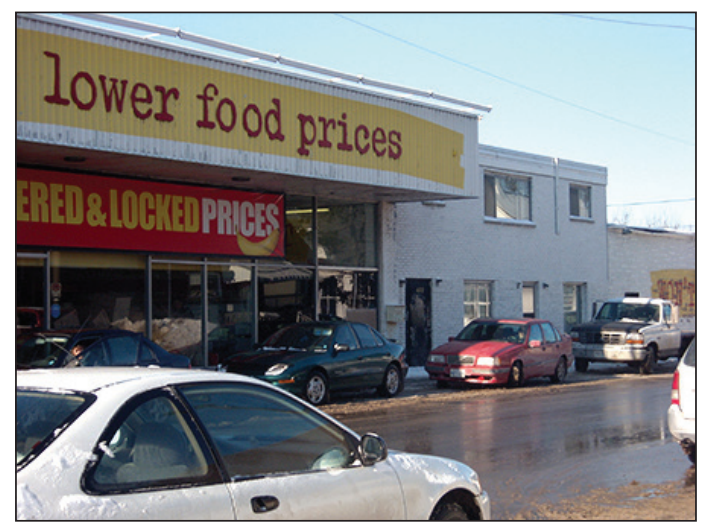

Figure 2: Grant's No Frills, 2008

Source: Author 